\title{
Effects of Use of Instructional Materials on Students Cognitive Achievement in Agricultural Science
}

\author{
Matthew C. Nwike \\ Federal College of Education(Technical), \\ Umunze-Anambra State, Nigeria \\ Onyejegbu Catherine \\ Department of Natural Science \\ School of General Studies \\ Federal Polytechnic, Oko-Anambra State, Nigeria
}

Doi:10.5901/jesr.2013.v3n5p103

\begin{abstract}
The study to find out the effects of use of instructional material on students cognitive achievement in agricultural science in secondary schools of Orumba South Local Government Area. Quasi experimental design was used. The sample comprised of 256 J S // students randomly sampled from 5 schools drawn from 5 towns in the local Government Area. The students were divided into two groups (experimental and control, group). An Agricultural Achievement Test $(A A T)$ of reliability 0.82 was used for the study. The experimental group was taught using instructional materials while the control group was taught without instructional materials. Data collected was analyzed using mean, standard deviation and z-test statistics. The findings revealed that students taught with instructional materials performed better than those taught without instructional materials. Also there is no significant difference in the mean achievement scores of male and female students. The null hypothesis tested at 0.05 level of significance indicated that there is significant difference between the achievement scores of those taught with instructional materials and those taught without instructional materials. It was therefore recommended that instructional materials be used in teaching in secondary schools because it has positive impact on student's performance.
\end{abstract}

\section{Introduction}

Effective teaching of any subject will not only stimulates student's interest in the subject but also enhance their achievement in the examination. To achieve effective teaching and learning process, there is the need for use of instructional materials.

Instructional materials are the different teachigng aids or apparatus which a classroom teacher employs to facilitate his or her teaching for the achievement of the stated objective. Agun (1992) defined instructional materials as those materials which are helpful to the teachers and students and which maximize learning in various areas. The use of instructional materials in teaching of agricultural science is very important because it provides a concrete basis for conceptual thinking motivates people to learn and captures pupils' imagination if used correctly (Ajalla, 1997).

The cognitive domain of learning involves knowledge and the development of intellectual skills. It includes the recognition of specific facts, procedural patterns and concepts that serve in the development of abilities and skills Achievement test is a test given at the end to find out the 
extent to which a student has achieved something, acquired certain information or mastered certain skill as a result of planned instruction or training. The importance of instructional materials in teaching and learning of agricultural science especially at the primary and Junior Secondary Schools cannot be over emphasized considering its effect on the development of intellectual skills on the students.

\section{Statement of the Problem}

The use of instructional materials in schools is not encouraging. As a result, it makes the morale and interest of the students in agricultural science low. This is because teachers adopt the verbalistic and theoretical method as a way of teaching and learning the subject, mainly due to non- availability of instructional material in schools. The question now is, to what extent does the use of instructional materials effect learning and students achievement in agricultural science in secondary schools.

\section{Purpose of the study}

The aim of the study is to determine the effect of use of instructional material on student's achievement in agricultural science in secondary schools. Specifically, the study intends to:

1. Find out the mean achievement scores of students taught with instructional materials and those taught without instructional material in agricultural science

2. Determine if such effect depended on the sex (gender) of students

\section{Research Questions}

The following research questions guided the study

1. What is the mean achievement scores of agricultural science students taught with instructional materials and those taught without instructional materials?

2. What are the mean achievement scores of male and female students taught with instructional materials?

\section{Hypothesis}

The Null hypothesis was tested at 0.05 level of significance

$\mathbf{H O}_{1}$ : There is no significant difference between the mean cognitive achievement scores of students taught with instructional materials and those taught without instructional materials.

\section{Methodology}

Research Design: Quasi experimental design was used.

Area of Study: The study was conducted in secondary schools of Orumba South L.G.A. There are a total of 16 secondary schools in Orumba South L.G.A

\subsection{Population of the Study}

The population for the study comprises of all JSS II students in the 16 secondary schools in Orumba south L.G.A, the total number of the JSS II student is 705 (Source: Statistics Unit, Orumba South Local Government Headquarter Umunze) 


\subsection{Sample and Sampling Techniques}

Simple random sampling was used in selecting five towns, from each of the five towns one secondary school was selected by random sampling. This gave a total of five secondary schools, with 258 J SS II students.

\subsection{Instrument}

An instrument known as Agricultural science Achievement test (AAT) was used for data collection. The agricultural science achievement test developed by the researchers consists of eighteen questions.

\subsection{Validation of the Instrument}

The instrument was validated by two lecturers in agricultural education of F.C.E (T) Umunze and one agricultural science teacher in one of the sample schools. They criticized the lesson notes and necessary amendments were made.

\subsection{Reliability of the Instrument}

The reliability of the test was estimated by test-retest on 49 agricultural Science Students in J unior Secondary II Onitsha the study area. The reliability coefficient of 0.82 was obtained using Pearson Product Moment Correlation.

\subsection{Experimental Procedure}

There were two groups, the experimental group who were taught using instructional materials while the control group was taught without instructional materials. The Agricultural Science teachers were used in administering the instrument for four periods of 40 minutes each per group.

\subsection{Method of data analysis}

The research questions were answered using means and standard deviations, while the hypotheses were tested at 0.05 level of significance using Z-test Statistics.

\section{Results}

The result of the study are presented below

Research Question I: What is the mean achievement scores of agricultural science students taught with instructional materials and those taught without instructional materials

Table I: Mean Achievement Scores and Standard deviations of students taught with instructional materials and those taught without instructional materials.

\begin{tabular}{|c|c|c|c|}
\hline Group & Number & Means $\overline{\mathbf{x}}$ & Standard Deviation \\
\hline Experiment & 132 & 15.30 & 1.81 \\
\hline Control & 126 & 10.79 & 4.44 \\
\hline
\end{tabular}

Data in Table I revealed that the mean achievement scores of experimental group and control group was 15.30 and 10.79 respectively. The experimental group therefore performed better than the control group. 
Research Question 2: What are the mean achievement scores of male and female students taught with instructional materials?

Table 2: Mean achievement scores and standard deviation of male and female

\begin{tabular}{|c|c|c|c|}
\hline Gender & Number & Mean & Standard Deviation \\
\hline Male & 69 & 12.35 & 3.95 \\
\hline Female & 61 & 12.36 & 4.67 \\
\hline
\end{tabular}

The mean achievement scores of male students and female in table 2 were 12.35 and 12.36 respectively and standard deviation was 3.95 and 4.67 respectively. This indicates that there is no much difference between mean scores of male and female students

\section{Hypothesis}

There is no significant difference between the mean cognitive achievement scores of students taught with instructional materials.

Table 3: Z-test table for mean scores of students taught with instructional materials and those taught without instructional materials.

\begin{tabular}{|c|c|c|c|c|c|c|c|}
\hline Group & $\mathbf{N}$ & $\overline{\mathbf{X}}$ & SD & Df & Z-cal & Z-crit & Decision \\
\cline { 1 - 4 } Experimental Group & 132 & 15.30 & 1.81 & \multirow{2}{*}{256} & 10.81 & \multirow{2}{*}{1.96} & $\begin{array}{c}\text { Reject } \\
\mathrm{Ho}_{1}\end{array}$ \\
\hline Control Group & 126 & 10.76 & 4.44 & &
\end{tabular}

In table 3 above, the calculated $Z$ was 10.81 while the critical Z was 1.96 . Since the calculated Z was greater than the critical $Z$ under degree of freedom of 256 and 0.05 level of significance, the null hypothesis was rejected. This means that a significant difference exists in the mean scores of students taught with instructional materials and those taught without instructional materials.

\section{Discussion}

The findings of research question I revealed that those students taught with instructional materials performed better than those taught without instructional materials. This finding is in line with the work of Olagunju (2000) who found out that there was a remarkable difference in the achievement scores of students taught with various instructional materials and those not exposed to use of instructional materials. There is therefore a general consensus that instructional materials enhances teaching \& learning and leads to better students' achievement.

Research question 2 seeks answer to the extent to which gender affects the mean achievement scores of students taught with instructional material. The findings revealed that the mean achievement scores of male and female students were almost the same. Alio and Ezemaenyi (2010) reported insignificant difference in the mean scores of male and female students taught with instructional materials. It can be deduced that gender plays no effect on the achievement of students exposed to instructional materials. The test of null hypothesis showed that there was a significant difference between the mean achievement scores of students taught with instructional materials and those taught without instructional materials.

\section{Recommendations}

Based on the findings of the study the following are recommended 
1) Government should provide instructional materials in secondary schools to enhance effective teaching and learning.

2) Enough time should be allotted in the school time table for effective use of instructional materials in teaching agricultural science.

3) Seminars, workshop on the use of the instructional materials should be organized for agricultural science teachers.

4) Teachers and students should be encouraged to form the habit of improvising instructional materials to make up the shortfall in supply.

5) There should be defined relationships between the course of study and materials to be used for effective teaching of agricultural science.

\section{Conclusion}

From the findings the study, it can be seen that students taught with instructional materials performed better than those taught without. This shows that students learn and perform better when they are taught with instructional materials because the use of instructional materials gives the students the opportunity to see, feel and touch the materials during teaching.

\section{References}

Alio, B.C. and Ezeamaenyi .O. (2010) Journal of Education for Professional Growth Association of Educationists for Professional Growth in Nigeria (ASEPGN) 6(1)

Agun, I. (1992) I mportance of Audio visual Instruction. West African J ournal of Education 20 (2)

Ajalla, A.A. (1997) Availability of Educational of Pre-vocational Agricultural science in secondary schools in Anambra state. J ournal of research in learning and teaching 1(1).

Olagunju, I. (2000) Strategies \& Utilization of Improvised Biology of Instructional Materials and Students. Achievement and attitudes in Ekiti State Secondary Schools Nigeria. International Journal of Research in Education 3(2) 
